\title{
Markt und Innovationen
}

\section{DATEN - FAKTEN - PRAXIS}

Aktuelle Meldungen und Neuigkeiten aus den Unternehmen.

Die Beiträge dieser Rubrik beruhen auf Informationen der Hersteller und geben nicht die Meinung des Verbands, der Redaktion und des Verlags wieder.

๑) Springer Medizin Verlag GmbH 2017

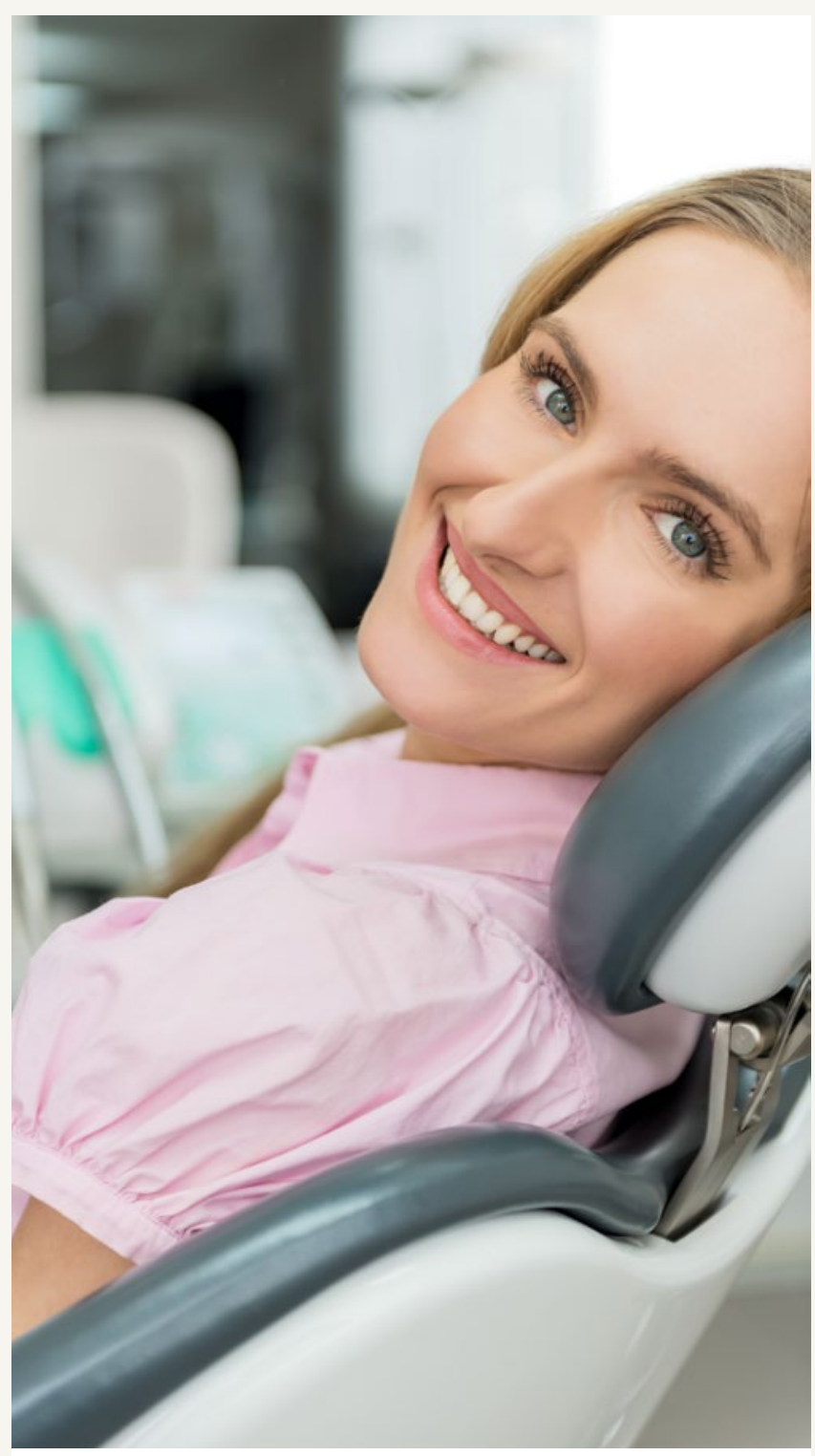

